TEORIAS DA JUSTIÇA

\title{
A complementaridade entre os aspectos liberais e republicanos na filosofia política de Rousseau
}

\author{
Joel Thiago Klein ${ }^{1}$ \\ Cristina Foroni Consani ${ }^{2}$
}

Resumo: este artigo apresenta os aspectos liberais e republicanos da filosofia política de Rousseau e defende que eles devem ser interpretados como complementares. Entretanto, essa complementaridade pode ser caracterizada num sentido específico, qual seja, como sendo um liberalismo republicano.

Palavras-chave: Rousseau; liberdade; igualdade; liberalismo; republicanismo.

\begin{abstract}
: this paper presents the liberal and republican aspects of Rousseau's political philosophy and argues that they should be interpreted as complementary. However, this complementarity can be characterized in a specific sense, namely, as Republican liberalism.
\end{abstract}

Key-words: Rousseau, liberty; equality; liberalism; republicanism

${ }^{1}$ Professor Adjunto do Departamento de Filosofia da UFRN. Pesquisador do CNPq. Essa pesquisa também recebeu suporte do CNPq (Processo n. 477298/2013-3). $<$ jthklein@yahoo.com.br>

${ }^{2}$ Professora Colaboradora vinculada ao Departamento de Direito Processual e Propedêuticas da UFRN < crisforoni@yahoo.com.br> 


\section{Introdução}

4 ste artigo busca apresentar e avaliar as tensões e uma possível complementaridade entre os aspectos liberais e republicanos presentes na filosofia política de Rousseau. Sustenta-se aqui a existência de uma estreita interconexão entre as noções de liberdade do indivíduo e de liberdade da comunidade política na obra do genebrino, a qual se apresenta como uma frutífera chave de leitura para se acomodar as ambiguidades e tensões existentes no que diz respeito, por um lado, às passagens em que ele coloca ênfase sobre os interesses do indivíduo e, por outro, naquelas em que ele coloca ênfase sobre o interesse público.

Para caracterizar e sustentar essa chave de leitura acerca da obra de Rousseau, o presente artigo se divide em quatro seções. Na primeira, apresenta-se, ainda que de modo não exaustivo, algumas conceituações centrais acerca da teoria liberal e da teoria republicana. $\mathrm{Na}$ segunda seção, apresenta-se e analisa-se diversas passagens da obra de Rousseau nas quais se encontram marcadamente características liberais juntamente com a indicação de algumas interpretações que seguem esse viés. $\mathrm{Na}$ terceira seção, por outro lado, tem-se o mesmo objetivo e adota-se a mesma estratégia da segunda seção, mas agora com relação aos aspectos republicanos. A quarta e última seção faz um balanço e uma sistematização das passagens e dos argumentos apresentados ao longo do texto e apresenta de modo sintético as razões pelas quais se sustenta que faz sentido ler a obra político-moral de Rousseau como sendo uma obra que procura equilibrar aspectos liberais e republicanos de modo que, em certo sentido, poder-se-ia caracterizá-la como uma teoria liberalrepublicana. De modo geral, as três primeiras seções possuem um caráter meramente reconstrutivo, sendo que é na quarta seção que se encontra a tese desse artigo. Além disso, as interpretações apresentadas na segunda e terceira seção não pretendem ser exaustivas e foram escolhidas justamente por que elas conduzem e, em certo sentido, corroboram a leitura apresentada e defendida na última seção.

\section{Características das tradições liberal e republicana}

Rousseau define República como sendo "todo o Estado regido por leis, qualquer que seja a sua forma de administração, porque só então o interesse público governa e a coisa pública significa algo." (ROUSSEAU, 1999, p.48) Atendo-se a essa definição pareceria incontestável considerar Rousseau como um republicano no sentido próprio do termo, contudo as coisas não são assim tão simples, pois essa definição de República é uma definição de Estado a qual, em geral, toda a tradição liberal também aceita. Nesse caso, República não seria mais do que o Estado da "rule of law", no qual todos os poderes estariam submetidos ao direito. Essa convergência se deve ao fato do Republicanismo e do Liberalismo 
possuírem um tronco comum, o qual é exatamente o ponto central da definição de Rousseau. Assim, para se compreender de modo mais nuançado a questão dos aspectos republicanos e liberais é necessário compreender em que sentido o governo das leis se relaciona com a questão da liberdade individual e em que sentido ele busca garantir e promover a liberdade política.

\subsection{Liberalismo}

Para se conceituar o liberalismo, faz-se uso aqui de duas definições que talvez sejam as mais aceitas pela tradição filosófica moderna e contemporânea. A primeira definição remonta às teorias de Locke e de Mill. Ela tem como noção central a individualidade, a qual depende de uma esfera de liberdade para atuação do indivíduo que normalmente se vincula a afirmação de direitos individuais que restringem o exercício do poder político sobre os indivíduos. Nesse sentido, embora se reconheça a importância da cultura e dos costumes, não se admite de modo algum a supremacia da comunidade sobre o indivíduo.

Assim, o reflexo do liberalismo moderno na liberdade individual é a exigência de proteção institucionalizada às liberdades intelectuais e pessoais tais como: liberdade de expressão, de associação, liberdades civis, liberdade de religião e de estilo de vida. No âmbito econômico requer-se liberdade de propriedade e de contratos, ou seja, o Estado não tem o direito de regular a economia, estabelecendo, por exemplo, condições para que um contrato seja considerado legítimo. Também não cabe ao Estado qualquer regulamentação acerca da distribuição de bens e riquezas na sociedade, ou mesmo a reserva e controle de recursos naturais (cf. WALDRON, 1993, p. 1, 2, 38).

Pode-se incluir ainda nesta caracterização do liberalismo moderno o pressuposto kantiano da prioridade do justo sobre o bem, o que significa que o Estado, em suas regulações, deve ser neutro em relação a concepções substantivas do que seria bom para o indivíduo (religião, tradição, cultura). Nesse sentido, o Estado não deve se ocupar do conceito de felicidade que os seus cidadãos possuem, mas deve se ocupar apenas dos princípios de justiça. ${ }^{3}$

A segunda definição, mais contemporânea e ligada ao pensamento de filósofos políticos anglo-americanos, associa o termo "liberal" a teorias

\footnotetext{
${ }^{3}$ Sobre isso ver: "Um governo que se erigisse sobre o princípio da benevolência para com o povo à maneira de um pai relativamente a seus filhos, isto é, um governo paternal (imperium paternale), onde, por conseguinte, os súditos, como crianças menores que ainda não podem distinguir o que lhes é verdadeiramente útil ou prejudicial, são obrigados a comportar-se apenas se modo passivo, a fim de esperarem somente do juízo do chefe de Estado a maneira como devem ser felizes, e apenas da sua bondade que ele também o queira - um tal governo é o maior despotismo que se pode pensar (constituição, que suprime toda a liberdade dos súditos, os quais, por conseguinte, não tem direito algum)." (KANT, 2002, 75)
} 
que vinculam a liberdade à igualdade de oportunidades, ou seja, defendem que todos os indivíduos devem possuir "igual liberdade". Desse modo, os adeptos dessa concepção de liberalismo apoiam políticas públicas destinadas a: reduzir a desigualdade, assegurar um patamar mínimo de bem-estar social, regular as atividades econômicas no interesse da saúde e segurança dos trabalhadores e do meio ambiente, a promover igualdade sexual e racial, enfim, a promover o bem comum (cf. WALDRON, 1993, p. 2). A teoria da Justiça como equidade de John Rawls é um bom exemplo desse tipo de liberalismo que passou a ser chamado de liberalismo igualitário.

É importante ressaltar que apesar do discurso das virtudes não estar no núcleo das teorias liberais, isso não significa que as virtudes sejam desconsideradas. Pode-se falar, por exemplo, de "virtudes liberais" (cf. HOLMES, 1993; DAGGER, 1997; RAWLS, 2000 e 2002), as quais, por exemplo, também fecham em certo sentido a abóboda do pensamento político de Locke e de Mill. Entretanto, essas virtudes liberais estão muito mais próximas da noção de "interesse bem compreendido", tal como desenvolvida por Tocqueville (2000), do que da noção de uma vida ativa dedicada ao bem comum da comunidade política e do Estado, tal como ocorre marcadamente na tradição republicana.

\subsection{Republicanismo}

A tradição republicana também apresenta uma pluralidade de posições bastante variadas que remontam a pensadores de épocas muito distintas, tais como Cícero, Maquiavel e Madison. Por essa razão, não é tarefa fácil encontrar uma definição. Nesse caso, parece mais adequado se falar em elementos comuns entre essas variadas concepções republicanas, dos quais se destacam dois,' a saber: a) preocupação com a sobrevivência das instituições políticas; e b) a necessidade de eliminar aspectos negativos da natureza humana que comprometem a o agir político direcionado ao bem comum (paixões, interesses egoístas, por exemplo) (cf. PINZANI, 2007).

É possível mencionar ao menos duas tentativas diferentes de sistematizar as teorias republicanas. Uma delas é oferecida por Robert Dahl em Democracia e seus críticos. Segundo Dahl, a tradição republicana teria duas vertentes, a saber, a democrática e a aristocrática. A vertente democrática vê no predomínio de grupos dominantes (no âmbito político ou econômico) um risco de degeneração oligárquica da República. Portanto, confia-se no governo popular e desconfia-se das elites. Talvez o modelo mais radical dessa vertente seja a Atenas do ostracismo. Já a vertente aristocrática teme as decisões de uma maioria plebeia, a qual é considerada como facilmente manipulável, corruptível e incapaz de reconhecer o bem comum. (cf. DAHL, 1989, p. 25/26) Entretanto, ambas as vertentes operam com pares conceituais que expressam um conflito entre 
o interesse privado e o bem comum, e sustentam que o egoísmo dos cidadãos tende a levar à ruína do Estado caso as instituições não atuem para evitar isso.

Uma segunda proposta de categorização do republicanismo é apresentada em $A$ constituição da República de Günter Frankenberg. Ele defende que a tradição republicana pode ser analisada a partir de duas soluções: a externalista e a internalista. A solução externalista confia a sobrevivência e o sucesso das repúblicas às instituições (leis), as quais devem ser geradas, garantidas e implementadas pela atuação ativa do aparato estatal (cf. FRANKENBERG, 1997, p. 137). A solução internalista deposita suas expectativas de sobrevivência da república nas virtudes cívicas, na religião civil e no patriotismo tradicional ou constitucional. Maquiavel é um dos que sustenta essa tese: "As leis e instituições estabelecidas na origem de uma república, quando os cidadãos eram virtuosos, se tornam insuficientes quando eles começam a se corromper" (MAQUIAVEL, 2000, p. 75). É importante observar que as soluções internalista e externalista se encontram em geral associadas, mas ocorre que uma ou outra tem maior relevância em determinados autores e teorias.

Em suma, a partir dessas tentativas de classificação pode-se afirmar que a tradição republicana coloca seu foco nos seguintes elementos: interesse público (vs. interesses privados e egoístas); boas leis e bons costumes (vs. leis parciais e degeneradas); cidadãos virtuosos, isto é, cidadãos que se dedicam continuamente para a promoção do bem comum (vs. cidadãos corruptos ou facciosos); promoção de uma certa igualdade formal e material entre os cidadãos (vs. igualdade meramente formal).

\section{Os aspectos liberais da filosofia política de Rousseau}

As interpretações que apontam para os aspectos liberais da obra de Rousseau buscam sustentar que toda a sua filosofia política procura garantir a individualidade na medida em que congrega dois elementos centrais da teoria liberal, a saber, a proteção aos interesses dos indivíduos e a proteção aos direitos e liberdades privadas. Nesta seção, apresentamse os argumentos e as passagens de duas relevantes leituras que defendem essa posição, a saber, a de John Rawls e a de Joshua Cohen.

Apesar de também encontrar uma defesa dos interesses individuais e dos direitos liberais nos trabalhos biográficos de Rousseau (Confissões; Diálogos - Rousseau juiz de Jean-Jacques; Devaneios de um caminhante solitário), Rawls centra sua análise nas obras políticas, especialmente em O contrato social e no Discurso sobre a Economia Política.

Partindo da análise da polêmica frase de Rousseau, a qual considera "os homens tais como eles são e as leis tais como elas podem ser" (ROUSSEAU, 1999, p. 7), Rawls sustenta que se trata de uma tentativa de estabelecer equilíbrio entre o que o direito permite e o que prescreve o 
interesse (RAWLS, 2007, p. 215). A frase "os homens como eles são" é ambígua, pois não se refere às pessoas como elas são agora (antes do contrato), com vícios e hábitos corrompidos pela civilização, mas a seres humanos como eles são de acordo com os princípios básicos e propensões da natureza humana. Em outras palavras, segundo Rawls (2007, p. 225s), Rousseau não define as pessoas como elas são na sociedade marcada por extremos de desigualdades, da qual resulta o mal da dominação e da sujeição; mas ele define os seres humanos como eles são na natureza, é a natureza que determina os interesses fundamentais. Em suma, segundo Rawls (2007, p. 227s), na obra de Rousseau os interesses fundamentais são determinados pela natureza humana comum, ou pela concepção de Rousseau de pessoa, que é uma ideia normativa.

Nesse sentido, a leitura de Rawls sustenta que a vontade geral, aquela que funda o contrato social, não é um somatório de interesses egoístas já corrompidos pelo processo civilizatório, mas a expressão fundamental dos verdadeiros interesses e propensões da natureza humana, os quais são basicamente dois, a capacidade para a vontade livre e a perfectibilidade (potencial para o auto aprimoramento). Ora, como a individualidade está estreitamente ligada com esses dois interesses, pode-se dizer que, a vontade geral deve ser exatamente aquela que busca garantir o direito à individualidade.

Segundo Rawls, a vontade geral não é uma entidade que transcende os membros da sociedade, mas é a vontade da sociedade como um todo que está presente em cada cidadão. ${ }^{4}$ São os indivíduos que possuem uma vontade geral, que é a capacidade para a razão deliberativa que, em ocasiões apropriadas, os guia a decidir o que fazer, como votar, o que dizer, com base no que é necessário para sua preservação comum (cf. RAWLS, 2007, p. 224). Assim, para Rawls, o que torna o bem comum possível são os interesses comuns; o bem comum é formado pelas condições sociais que tornam possível cidadãos amarrarem seus interesses comuns. O que torna possível os interesses comuns que especificam o bem comum são os interesses fundamentais que atuam como premissas. Essas premissas, que incluem os interesses fundamentais, estão, segundo Rawls, implícitas nas características gerais do pacto social de Rousseau e são as quatro seguintes:

i) interesses fundamentais: o Contrato social precisa levar em conta os interesses fundamentais associados ao amor próprio e ao amor de si. O amor de si se vincula com a capacidade para ter uma vontade livre, capacidade para agir à luz de razões válidas; capacidade de

\footnotetext{
${ }^{4}$ Uma condição essencial da sociedade do Contrato Social é que ela não é uma mera agregação de pessoas, mas seus membros possuem uma vontade geral (cf. RAWLS, 2007, p. 224). Ou seja, como membros de uma sociedade política, os cidadãos compartilham uma concepção de bem comum. Rawls cita novamente Rousseau: "Enquanto muitos homens reunidos se consideram como um só corpo, têm uma só vontade que se refere à conservação comum e ao bem-estar geral". (ROUSSEAU, 1999, p. 125)
} 
perfectibilidade e de autoaprimoramento de nossas faculdades por meio de nossa participação na cultura desenvolvida ao longo do tempo, capacidade para o pensamento intelectual, para atitudes morais, para sentir emoções e capacidade de identificação com os outros, tal como piedade e compaixão). Já o amor próprio se vincula com a necessidade que temos de ser reconhecidos pelos outros como tendo uma condição de iguais no grupo social, isto é, condição de reciprocidade que impõe limites à conduta dos outros (cf. RAWLS, 2007, p. 217s.).

ii) condições de interdependência social entre os indivíduos: Rousseau supõe que "os homens tenham chegado àquele ponto em que os obstáculos prejudiciais à sua conservação no estado de natureza sobrepujam, por sua resistência, as forças que cada indivíduo pode empregar para ser manter nesse estado" (ROUSSEAU, 1999, p. 20). Mas Rawls chama a atenção para que o fato de que interdependência não significa dependência. Nesse caso, Rousseau pressupõe o indivíduo completamente dependente da sociedade como um todo e independente de outros cidadãos como indivíduos. Rawls apoia-se no seguinte excerto do Contrato Social:

A segunda relação é a dos membros entre si ou com o corpo todo, e essa relação deve ser no primeiro caso tão pequena e no segundo tão grande quanto possível, de sorte que cada cidadão esteja em perfeita independência de todos os outros e em excessiva dependência da Cidade; o que se consegue sempre pelos mesmos meios, pois só a força do Estado faz a liberdade de seus membros. É dessa segunda relação que se originam as leis civis. (ROUSSEAU, 1999, p. 65s.); (RAWLS, 2007, p. 218)

iii) todas as pessoas têm uma igual capacidade para e interesse em sua liberdade: trata-se de uma capacidade igual para julgar o que é melhor para seu próprio bem e desejo de agir nesse sentido e, além disso, considera-se que as pessoas têm uma capacidade igual para o senso político de justiça e um interesse em agir de acordo com isso, isto é, uma capacidade para compreender, aplicar e agir de acordo com os princípios do pacto social (cf. RAWLS, 2007, p. 219). O trecho que corrobora tal leitura é o seguinte: "A passagem do estado de natureza ao estado civil produz no homem uma mudança considerável, substituindo em sua conduta o instinto pela justiça e conferindo às suas ações a moralidade que antes lhes faltava." (ROUSSEAU, 1999, p. 25)

iv) O contrato social visa o bem comum que protege os direitos e se afasta da noção utilitarista de bem. Segundo Rawls (2007, 229), o bem comum na obra de Rousseau não pode ser considerado em termos 
utilitaristas. ${ }^{5}$ Isso ficaria claro no seguinte excerto no Discurso sobre a Economia Política:

Mas se devemos entender que é legal para o governo sacrificar um inocente pelo bem da multidão, considero essa regra a mais execrável já inventada pela tirania, a maior falsidade que pode ser proferida, a admissão mais perigosa, uma contradição direta com as leis fundamentais da sociedade. (ROUSSEAU, 2003, p. 20).

De acordo com Rawls, essa passagem mostra que Rousseau não admite que as leis fundamentais do pacto social sejam fundadas num princípio agregativo. Outra passagem do Contrato Social é invocada para reforçar essa tese:

A primeira e mais importante consequência dos princípios acima estabelecidos é que só a vontade geral pode dirigir as forças do Estado em conformidade com o objetivo de sua instituição, que é o bem comum: pois, se a oposição dos interesses particulares tornou necessário o estabelecimento das sociedades, foi o acordo desses mesmos interesses que o tornou possível. O vínculo social é formado pelo que há de comum nesses diferentes interesses, e, se não houvesse um ponto em que todos os interesses concordam, nenhuma sociedade poderia existir. Ora, é unicamente com base nesse interesse comum que a sociedade deve ser governada. (ROUSSEAU, 1999, p.33).

Em resumo, a tese de Rawls é que os interesses e liberdades individuais são preservados na sociedade criada pelo Contrato Social do seguinte modo: as leis fundamentais são baseadas no interesse comum, o qual, por sua vez, abarca os interesses fundamentais dos indivíduos. Os interesses fundamentais, por sua vez,

incluem os interesses expressos pelas duas formas naturais de amor de si (amour de soi e amour-propre) tanto quanto nossos interesses na segurança de nossa pessoa e propriedade. Segurança e propriedade, ao invés de mera posse, é uma das vantagens da sociedade civil (CS, 1:8.2). Há também nossos interesses nas condições para o desenvolvimento de nossas potencialidades (para a vontade livre e perfectibilidade) e nossa liberdade para alcançar os nossos objetivos que achamos convenientes, dentro dos limites de nossa liberdade civil. (RAWLS, 2007, p. 230)

Esses interesses fundamentais seriam compartilhados por todos e, por essa razão, deveriam ser assegurados por leis através da cooperação social em termos que todos pudessem concordar. $\mathrm{Na}$ elaboração das leis,

\footnotetext{
${ }^{5}$ A defesa da vontade geral em termos utilitaristas é feita por Glen Allen. Segundo o autor: "a vontade geral é de fato nada mais do que um critério para a decisão social, o critério do maior bem do maior número, segundo o qual se assume que cada indivíduo deseja seu próprio bem." Cf. ALLEN, 1961, p. 265.
} 
esses interesses fundamentais teriam prioridade sobre os interesses particulares. Mas, de acordo com Rawls, isso não implica a anulação ou submissão do indivíduo à comunidade, pois nos interesses fundamentais os interesses individuais mais relevantes já estão presentes. Assim, pela natureza dos interesses fundamentais, incluindo o interesse de evitar condições pessoais de dependência, que podem ser evitadas se o amor próprio e a perfectibilidade não forem corrompidos e se os indivíduos não estiverem submetidos à vontade arbitrária e à autoridade particular de outros, a vontade geral tende à igualdade. Verifica-se, então, que a igualdade é necessária para a liberdade e a falta de independência pessoal significa a perda da liberdade. (cf. RAWLS, 2007, p. 233).

Rawls cita a seguinte passagem do Contrato Social:

Já disse o que é a liberdade civil; a respeito da igualdade, não se deve entender por essa palavra que os graus de poder e riqueza sejam absolutamente os mesmos, mas sim que, quanto ao poder, ela esteja acima de qualquer violência e nunca se exerça senão em virtude da classe e das leis, e, quanto à riqueza, que nenhum cidadão seja assaz opulento para poder comprar o outro, e nenhum assaz pobre para ser obrigado a vender-se. O que supõe, da parte dos grandes, moderação de bens e de crédito, e, da parte dos pequenos, moderação de avareza e de cobiça. (ROUSSEAU, 1999, p. 62s.)

É digno de nota que essa passagem invocada por Rawls para se referir à proteção dos interesses individuais pode também ser utilizada para apontar o republicanismo de Rousseau na medida em que serve para autorizar a intervenção do Estado para assegurar esse tipo de igualdade que, por sua vez, permite a liberdade e a independência dos cidadãos uns em relação aos outros. Rawls cita novamente Rousseau para mostrar que a lei deve tentar assegurar a igualdade: "É exatamente porque a força das coisas tende sempre a destruir a igualdade que a força da legislação deve sempre propender a mantê-la" (ROUSSEAU, 1999, p. 63).

$\mathrm{Na}$ análise de Rawls, os interesses e liberdades dos indivíduos estão protegidos na sociedade formada pelo Contrato Social porque não é qualquer lei que pode vincular e criar deveres e obrigações para os indivíduos, mas somente as leis fundamentais que foram votadas pelos cidadãos de acordo com o ponto de vista da vontade geral (cf. RAWLS, 2007 , p. 242). Uma vez que a vontade geral deve refletir os interesse fundamentais, e os interesses fundamentais abarcam os interesses e liberdades individuais, ao obedecer as leis fundamentais os indivíduos obedecem a leis com as quais eles concordaram e que contemplam seus interesses e liberdades. Em outras palavras, obedecendo às leis fundamentais promulgadas, os indivíduos realizam sua liberdade moral. (cf. RAWLS, 2007, p. 243). De acordo com Rawls, para Rousseau os interesses fundamentais são interesses regulativos, uma vez que no pacto social os indivíduos concordam em alcançar seus interesses privados 
dentro dos limites das leis políticas fundamentais aceitas pela vontade geral, a qual é sempre uma vontade guiada pelos interesses fundamentais compartilhados com os outros (cf. RAWLS, 2007, p. 244).

A leitura de Rousseau feita por Cohen é bastante semelhante àquela feita por Rawls. Segundo ele, a capacidade para a liberdade é, para Rousseau, uma capacidade para resistir às inclinações. Isso aparece no Emílio quando Rousseau afirma que a causa que determina a vontade é o julgamento, e o que causa o julgamento é a faculdade da inteligência, o poder de julgar, a suspensão das inclinações. Assim, a base da natureza do agente moral é a capacidade de agir como agente responsável. ${ }^{6}$ Por essa razão, renunciar à liberdade é como renunciar à capacidade de ser humano, de possuir direitos de humanidade e deveres (cf. COHEN, 2010, p. 28). Nesse sentido, lê-se no Contrato Social:

Renunciar à liberdade é renunciar à qualidade de homem, aos direitos da humanidade, e até aos próprios deveres. Não há nenhuma reparação possível para quem renuncia a tudo. Tal renúncia é incompatível com a natureza do homem, e subtrair toda liberdade a sua vontade é subtrair toda moralidade a suas ações. Enfim, é inútil e contraditória a convenção que estipula, de um lado, uma autoridade absoluta, e, de outro, uma obediência sem limites. (ROUSSEAU, 1999, p. 15) ${ }^{7}$

Segundo Cohen, Rousseau apresenta três argumentos contra a alienação da liberdade: $\left.1^{\circ}\right)$ argumento instrumental: a liberdade é um instrumento primário para a própria preservação do indivíduo; ${ }^{8} 2^{\circ}$ ) argumento da racionalidade: a liberdade é a mais nobre faculdade e o presente mais precioso de todos; ${ }^{9} 3^{\circ}$ argumento de natureza moral: os

${ }^{6}$ Trata-se do seguinte excerto: “Tenho sempre o poder de querer, não a força de executar. Quando me entrego às tentações, ajo conforme o impulso dos objetos externos. Quando me censuro por tal fraqueza, só ouço a minha vontade (...) Qual é então a causa que determina sua vontade? É o seu juízo. E qual é a causa que determina seu juízo? É a sua faculdade inteligente, é sua potência de julgar; a sua determinante está nele mesmo." (ROUSSEAU, 2014, p. 395)

7 Nesse mesmo sentido No Discurso sobre a origem das desigualdades: "A natureza comanda todo animal e o animal obedece. O homem recebe a mesma instrução, mas se reconhece livre para concordar ou resistir, e é sobretudo na consciência dessa liberdade que se mostra a espiritualidade da alma humana" (ROUSSEAU, 2013, p. 56). Em outra passagem: "(...) sendo o direito de propriedade apenas de convenção e instituição humana, todo homem pode dispor à vontade do que possui, porém o mesmo não acontece com os dons essenciais da natureza, como a vida e a liberdade, de que cada um pode usufruir e dos quais no mínimo é duvidoso que se tenha o direito de abrir mão. Aquele, retirado, degrada o indivíduo, mas estes, retirados, aniquilam o que ele é em si; e como nenhum bem temporal pode compensar a vida e a liberdade, renunciar a elas, não importa a que preço for, seria ofender ao mesmo tempo a natureza e a razão." (ROUSSEAU, 2013, p. 103)

${ }^{8}$ Esse argumento encontra-se no Contrato Social: "(...) sendo a força e a liberdade de cada homem os primeiros instrumentos de sua conservação, como as empregará sem prejudicar e sem negligenciar os cuidados que deve a si mesmo?" (ROUSSEAU, 1999, p. 20)

${ }^{9}$ Cf.: "Sendo a liberdade a mais nobre das faculdades do homem (...)" (ROUSSEAU, 2013, p. 102). E também no Contrato Social: "Dizer que um homem se dá gratuitamente é dizer uma 
indivíduos mantém o controle sobre sua conduta e vinculam-se a padrões de conduta dos quais não podem escapar submetendo-se a outras pessoas; assim, o esforço para alienar a vontade não obtém sucesso, haja vista os indivíduos terem consciência de que estão submetidos a normas morais que possuem prioridade sobre a vontade de outro agente. ${ }^{10}$ (cf. COHEN, 2010, p.29s.)

Assim, segundo Cohen, o problema que Rousseau enfrenta em sua justificação da sociedade é como conciliar autonomia e vinculação social. A solução para este problema é a "sociedade da vontade geral" (cf. COHEN, 2010, p. 33), ou seja, conforme definido por Rousseau, é uma sociedade na qual "cada um de nós põe em comum sua pessoa e todo o seu poder sob a suprema direção da vontade geral; e recebemos, coletivamente, cada membro como parte indivisível do todo" (ROUSSEAU, 1999, p. 21s). A questão aqui é saber qual o lugar do indivíduo e dos interesses e liberdades particulares na vontade geral. Cohen reconhece que Rousseau dá margem para interpretações nas quais os interesses dos indivíduos se identificam e são absorvidos pela comunidade, ou, ainda, que a vontade geral requer a completa renúncia de todos os desejos particulares (COHEN, 2010, p. 35s). ${ }^{11}$ Segundo Cohen, todavia, tais leituras focaram nos exageros do próprio Rousseau deixando de fora os momentos em que ele enfatiza a possibilidade de uma "comunidade livre de iguais" sob condições em que o interesse particular é claramente considerado. Um bom exemplo disso seria o excerto abaixo:

Os antigos povos não são mais um modelo para os modernos; estão muito distantes de nós em todos os aspectos. Vós, sobretudo, genebrinos, ficai em vosso lugar, e não ide atrás de objetos elevados que vos apresentam para vos esconder o abismo que estão cavando diante de vós. Não sois romanos, nem espartanos; não sois nem mesmo atenienses. Deixai de lado esses grandes nomes que não vos servem para nada. Sois negociantes, artesãos, burgueses, sempre ocupados com vossos interesses privados, com vosso trabalho, com vosso comércio, vosso ganho, pessoas para quem até mesmo a liberdade não passa de um meio de aquisição sem obstáculo e de posse em segurança. Essa situação requer de vós máximas específicas. Não sendo ociosos como eram os povos antigos, não podeis, como eles, vos ocupar sem cessar do Governo: mas, pelo fato de que podeis menos vigiá-lo sem interrupção, ele deve ser instituído de modo que vos seja mais fácil ver suas manobras e prever seus abusos. (ROUSSEAU, 2006, p. 425/426)

coisa absurda e inconcebível; este ato é ilegítimo e nulo, pelo simples fato de que quem o pratica não está em seu juízo perfeito. Dizer o mesmo de todo um povo é supor um povo de loucos: a loucura não estabelece o direito." (Rousseau, 1999, p. 14)

10 Para Cohen, as passagens do Emilio e do Contrato Social citadas confirmam essa interpretação.

${ }^{11}$ Interpretações nesse sentido podem ser encontradas, por exemplo, em Allan Bloon (cf. BLOON, 1997, p. 143-167) e em Ernest Cassirer (cf. CASSIRER, 1999, p. 52-54). 
Com base em excertos como esses, Cohen defende que Rousseau mantém os interesses particulares de forma distinta do interesse comum, pois entende que ele não abraça uma forte concepção de unidade cívica tal como se encontra na República de Platão (cf. COHEN, 2010, p. 34).

Segundo Cohen, algumas passagens das Considerações sobre o governo da Polônia, que são invocadas para sustentar que os interesses individuais sucumbem perante 0 interesse público devem ser interpretadas do seguinte modo: Rousseau diz que a nação deve ser o principal negócio, mas não o único, assim como diz que o patriotismo deve ser a paixão dominante, mas não a única (cf. COHEN, 2010, p. 37).

Para Cohen, os intérpretes de Rousseau que defendem haver em sua obra a subsunção dos interesses particulares no interesse público confrontam duas ideias bem diferentes: a ideia de que a vontade geral é soberana ou suprema e a ideia de que ela é completa ou exaustiva. Segundo Cohen, a vontade geral é soberana, mas não é fonte exaustiva de razões de conduta. Em outras palavras, os indivíduos possuem interesses particulares na sociedade criada pelo contrato e não renunciam a esses interesses. Isso porque Rousseau estaria preocupado em estabelecer uma hierarquia entre as vontades, com primazia da vontade geral, mas não em reduzir a vontade particular à vontade geral. Rousseau buscaria uma unidade por meio da ordenação das vontades, enquanto num projeto como o de Platão se verifica a unidade por meio da integração (cf. COHEN, p. 3840). Isso estaria indicado na seguinte passagem:

(...) se a oposição dos interesses particulares tornou necessário o estabelecimento das sociedades, foi o acordo desses mesmos interesses que o tornou possível. O vínculo social é formado pelo que há de comum nesses diferentes interesses, e, se não houvesse um ponto em que todos os interesses concordam, nenhuma sociedade poderia existir. Ora, é unicamente com base nesse interesse comum que a sociedade deve ser governada. (ROUSSEAU, 1999, p. 33)

Os interesses dos indivíduos estariam então contemplados na vontade geral ao coincidirem com o bem comum. Como ressalta Cohen, Rousseau pouco discorreu a esse respeito, mas isso pode ser reconstruído tendo em vista o panorama mais amplo de sua obra. Nesse sentido, o conteúdo do bem comum poderia ser delimitado a partir de quatro considerações, a saber (cf. COHEN, p. 40-54):

i) o bem comum é distributivo e não agregativo: isso significa que o bem comum não é a maximização do prazer agregativo, isto é, não pode ser entendido em termos utilitaristas como a maximização das satisfações individuais, mas, ao contrário, deve ser pensado como o compartilhamento de interesses com relação à segurança pessoal, de bens e da liberdade;

ii) o bem comum é a igualdade: compreendida como igual consideração atribuída a todos os membros da sociedade política, haja vista o contrato 
social estabelecer entre os cidadãos uma igualdade tal que todos comprometem a si mesmos sob as mesmas condições e todos devem gozar dos mesmos direitos, sendo totalmente arbitrário o estabelecimento de uma condição mais onerosa para alguns. Nesse sentido, o principal comprometimento dos indivíduos não seria imediatamente com o bem comum, mas apenas reflexivamente, haja vista que o acordo essencial é aquele que busca uma convivência conjunta em uma sociedade política governada por um compromisso compartilhado para limitar os encargos sobre outros. A igualdade, neste caso, equipara-se à justiça; ${ }^{12}$

iii) o bem comum visa à proteção da independência dos indivíduos: Rousseau teria feito concessões à independência individual (associada às liberdades pessoais e de consciência, à liberdade dos modernos como definida por Constant) ao estabelecer os limites dentro dos quais o poder soberano pode atuar, ou seja, a proteção à independência dos indivíduos configura-se pela estreita vinculação da lei ao bem comum e, nesse sentido, propostas de regulamentação que não possam ser plausivelmente sustentadas como contribuindo ao bem comum são consideradas arbitrárias e não permitidas porque não encontram suporte em razões apropriadas. ${ }^{13}$ Como já mencionado, segundo essa interpretação, a vontade geral não funda uma comunidade na qual os interesses particulares são completamente subsumidos no ideal de bem ou interesse comum. Em outras palavras, a vontade geral não demanda que os indivíduos renunciem a todos os seus interesses particulares, mas apenas que concedam prioridade ao interesse comum. Assim, a vontade geral pode ser considerada uma suprema direção, mas não uma direção exclusiva, ela aponta para a necessidade da primazia do cidadão sobre o indivíduo, do público sobre o privado, mas não para a exclusão do privado. A vontade geral estabeleceria, desse modo, uma unidade por integração e não uma unidade cívica completa como em Platão;

iv) o bem comum como fundamento do contrato social: se a igualdade de consideração de todos os membros é a condição pela a qual o próprio contrato social se funda e deve assegurar a independência em todas as áreas que não dizem respeito ao bem comum, a igualdade é tomada como o principal elemento definidor do bem comum. Esse ideal de igualdade deve ser considerado tanto em sentido formal (igualdade perante a lei) quanto em sentido material (igualdade de condições de vida). A igualdade formal ou de direitos encontra sua fundação na própria autoridade da vontade geral, uma vez que todos os direitos são fundados pelo contrato social e nenhum direito anterior é reconhecido, haja vista todos os direitos

\footnotetext{
${ }^{12}$ Nesse sentido são as passagens constantes do Livro I, Cap. VI e também do Livro II, Cap. IV do Contrato Social.

${ }^{13}$ Essa leitura encontra suporte no Livro II, Cap. IV do Contrato Social.
} 
serem fundados sob a consideração do bem comum que funciona como um padrão supremo da comunidade política. ${ }^{14}$

Ora, o que Rousseau quer dizer quando ele fala em "total alienação de direitos para a comunidade" (Rousseau, 1999, 21 /CS, Livro I, Cap. 6, §6)? Segundo Cohen, isso não significa que os membros da sociedade regulada pela vontade geral não possuem direitos, mas sim que a vontade geral é a própria fundação dos direitos nessa comunidade (cf. COHEN, 2010, p. 82). A base de todos os direitos é o Contrato Social e não uma espécie de intitulamento natural: “(...) Porque o Estado, perante seus membros, é senhor de todos os seus bens pelo contrato social, que no Estado serve de base a todos os direitos (...)" (ROUSSEAU, 1999, 27)

Cohen, assim como Rawls, entende que a existência de direitos básicos está implícita na noção de uma associação regulada pela vontade geral e direcionada ao bem comum, entendido de modo não agregativo. Os direitos são construídos como afirmação que deve haver o reconhecimento dos outros, assim, a existência da vontade geral requer o reconhecimento de direitos, porque isso implica um reconhecimento compartilhado do requerimento que aqueles interesses fundamentais serão protegidos e a supremacia desse requerimento em regular a associação. Em suma, o ponto central da afirmação de Rousseau sobre a alienação total é o seguinte: não significa que os membros da comunidade política não possuem direitos, mas que eles reivindicam esses direitos como membros e todos os direitos são fundados no bem comum, entendido de modo não agregativo. (cf. COHEN, 2010, p. 83)

Segundo Cohen, o bem comum seria o único meio pelo qual o povo asseguraria sua liberdade sob condições de interdependência. Assim, a ênfase na comunidade política é a contribuição distintiva de Rousseau para a teoria política e distingue sua teoria daquela de Hobbes e Locke, os quais veem o Estado como protetor dos indivíduos uns contra os outros e como uma instituição que capacita os indivíduos a perseguirem seus fins sem interferência. Para Rousseau, a liberdade como autogoverno requer a estrutura de uma comunidade política definida pela vontade geral. (cf. COHEN, 2010, p. 86)

A proteção aos direitos faz parte daquilo que Cohen chama de "argumento de princípio" na obra de Rousseau, o qual diz respeito aos

14 Essa interpretação apoia-se na seguinte passagem do Contrato Social: "Bem compreendidas, essas cláusulas se reduzem todas a uma só, a saber, a alienação total de cada associado, com todos os seus direitos, a toda a comunidade. Pois, em primeiro lugar, cada qual dando-se por inteiro, a condição é igual para todos, e, sendo a condição igual para todos, ninguém tem interesse em torná-la onerosa para os demais. Além disso, como a alienação se faz sem reservas, a união é tão perfeita quanto possível, e nenhum associado tem algo a reclamar, pois, se restassem alguns direitos aos particulares, como não haveria nenhum superior comum capaz de decidir entre eles e o público, cada qual sendo em algum ponto seu próprio juiz, logo pretenderia sê-lo em todos; o estado de natureza subsistiria e a associação se tornaria necessariamente tirânica ou vã." (ROUSSEAU, 1999, p. 21). 
direitos básicos de membros de uma comunidade livre de iguais e retira consequências institucionais desses direitos. Nesse sentido, direitos fundamentais estão implícitos na ideia de sociedade da vontade geral, com seu compromisso com uma concepção não agregativa de bem comum. Isso significa que a vontade geral é constitutivamente protetiva desses direitos, os quais comportariam os seguintes direitos básicos: i) segurança e liberdade pessoal e de bens ${ }^{15}$; ii) um nível de bem-estar suficiente para não ser obrigado a vender a si mesmo ${ }^{16}$; iii) direitos a independência pessoal (liberdades de consciência, pensamento, religião) ${ }^{17}$; iv) direito de participação na política (inalienabilidade da soberania) ${ }^{18}$

Ao colocar a foco de sua leitura da obra de Rousseau na individualidade, isto é, na proteção às liberdades, aos interesses e direitos do indivíduo, Rawls, e em certa medida também Cohen, acabam por fazer de Rousseau um precursor do liberalismo político, nos termos delineados pelo próprio Rawls. Nesse sentido, retornando às definições da teoria liberal apresentadas no início deste artigo, tais intérpretes não consideram Rousseau um liberal como Locke ou Mill, contudo, o aproximam do liberalismo igualitário.

O liberalismo igualitário poderia ser uma chave de leitura para tentar conciliar, na obra de Rousseau, a relação entre indivíduo e comunidade. Contudo, a igualdade proposta pelo liberalismo igualitário, bem como as virtudes cívicas que podem ser atreladas a esta teoria, são distintas daquelas delineadas por Rousseau. Como ficará claro na próxima seção, a igualdade proposta por Rousseau e as virtudes cívicas a ela atreladas, não se aproximam tanto da perspectiva de um "interesse bem compreendido", mas muito mais da criação de uma segunda natureza pelo trabalho das instituições (leis e costumes) e por uma virtude cívica direcionada fortemente para a noção de bem comum.

${ }^{15}$ A esse respeito, das Cartas escritas da Montanha extrai-se a seguinte passagem: "É preciso que os cidadãos tenham todas as garantias razoáveis, de tal modo que, cumprindo seu dever, possam dormir tranquilamente" (ROUSSEAU, 2006, p. 404). Ver ainda: "É certo que o direito à propriedade é o mais sagrado de todos os direitos da cidadania, e sob certos aspectos ainda mais importante do que a própria liberdade, ou porque afeta mais de perto a preservação da vida ou porque, como a propriedade é mais facilmente usurpada e mais difícil de defender do que a vida, a Lei deveria dar maior atenção ao que pode ser mais facilmente tomado. Ou ainda, finalmente, porque a propriedade é o fundamento da sociedade civil, e a verdadeira garantia dos esforços do cidadão. Se a propriedade não respondesse por ações pessoais, nada mais fácil do que escapar dos deveres e evadir-se da Lei." (Cf. ROUSSEAU, 2003, p. 27). Mais a frente "Vale lembrar que o fundamento do contrato social é a propriedade, e sua primeira condição é que todos possam manter a posse pacífica do que lhes pertence. É verdade também que, pelo mesmo contrato, todos se obrigam, pelo menos tacitamente, a contribuir para atender as demandas públicas (Cf. ROUSSEAU, 2003, p. 34)

${ }^{16}$ Cf. ROUSSEAU, 1999, 63.

${ }^{17}$ Cf. ROUSSEAU, 1999, 62.

${ }^{18}$ Cf. ROUSSEAU, 1999, 63. 


\section{Os aspectos republicanos da filosofia política de Rousseau}

Se Rawls e Cohen aproximam Rousseau do liberalismo igualitário e chamam a atenção para a preocupação do genebrino com a manutenção da individualidade consubstanciada nos interesses, direitos e liberdades privados, Cassirer é categórico ao afirmar que, se houve interesse do filósofo setecentista em proteger a vida particular da interferência política, este interesse esvaiu-se após a redação do Discurso sobre a origem da desigualdade. Desde o Contrato Social, Cassirer considera ter havido uma "reviravolta quase incompreensível" no pensamento rousseauniano, reviravolta esta que acaba por submeter os interesses individuais ao interesse da comunidade. Em suas palavras:

Rousseau torna-se autor do Contrato Social: escreve justamente para aquela sociedade, que ele repudiara e descrevera como causa de toda perversão e de toda infelicidade da humanidade, o seu código de leis. E como é esse código? Era de esperar que ele estabelecesse limites para a sociedade tão amplos quanto possível - que ele delimitasse e restringisse suas atribuições tão cuidadosamente de modo a rechaçar todo ataque à individualidade. Mas Rousseau nem de longe pensa numa tal 'tentativa de determinar os limites da atuação do Estado'. (CASSIRER, 1999, p. 52/53)

Ao considerar as passagens do Contrato Social nas quais Rousseau define a vontade geral, Cassirer vê nesse conceito a completa aniquilação dos interesses individuais. Em seu entendimento, o "Contrato social anuncia e glorifica um absolutismo totalmente livre da vontade estatal. Toda vontade individual e particular se quebra diante do poder da 'volonté generale'". (CASSIRER, 1999, p. 53) Desse modo, Cassirer visualiza nos capítulos iniciais do Contrato Social, sobretudo nas passagens em que Rousseau discorre sobre a alienação sem reservas dos indivíduos perante o pacto, uma tentativa de regular completamente a ação humana. E mais, visualiza ainda nos capítulos finais, nos quais surge a defesa de uma religião civil, uma proposta de regular também a consciência dos cidadãos. Diz Cassirer:

[o] final do Contrato Social aborda a implantação da 'religion civile', absolutamente obrigatória para todos os cidadãos. No tocante àqueles dogmas sem importância para a forma de vida coletiva, ele deixa ao indivíduo toda a liberdade, mas estabelece de maneira bem mais rígida uma série de artigos de fé que não admitem dúvidas, cuja pena é a expulsão do Estado. (CASSIRER, 1999, p. 53)

Não é apenas o Contrato Social, todavia, que chama a atenção dos intérpretes de Rousseau para eventuais sobreposições do interesse da comunidade aos interesses dos indivíduos. Os escritos constitucionais de Rousseau, notadamente o Projeto de Constituição para a Córsega e As 
considerações sobre o governo da Polônia apresentam passagens nas quais o genebrino acentua a necessidade de identidade cultural no intuito de preservar e fortalecer os laços comunitários. ${ }^{19}$

A leitura de Cassirer, mais do que apontar para a ênfase de Rousseau na comunidade, acaba mesmo por considerar que a comunidade absorve qualquer possibilidade de individualidade. Uma leitura republicana mais conciliadora entre a liberdade do indivíduo e o interesse da comunidade é feita por Bignotto. Segundo ele, (2010, p.90), foi a insistência com que Rousseau elogia Esparta e Roma, em particular seus personagens e a conduta moral de seus cidadãos, juntamente com as duras críticas aos costumes de sua época que alimentaram interpretações que sugerem que sua obra tenha sido precursora dos totalitarismos contemporâneos (cf. BIGNOTTO, 2010, p. 90). Além disso, o uso intensivo de Plutarco e de seus heróis, do ideal de rudeza e simplicidade de Esparta, juntamente com o tema da virtude traz a tona uma série de problemas que apontam para os riscos do pensamento de Rousseau, tais como a submissão total do cidadão ao Estado, porém, ele também ressalta que essa é apenas uma leitura possível, a qual não faz juz a complexidade da obra do genebrino (cf. BIGNOTTO, 2010, p. 104s.).

Um dos pontos que merecem destaque é o de que não há um sentido único de virtude no pensamento de Rousseau:

Há entre o indivíduo e o cidadão uma tensão que não parece ser inteiramente resolvida senão em momentos muito especiais da história. No Contrato Social, Rousseau investiga as condições em que esse encontro pode se dar de forma harmoniosa. Fora, porém, dessa configuração ideal, convivem no pensador genebrino dois modelos de vida que, sem ser excludentes, apontam para realidades bastante distintas. De um lado está a polis antiga com suas realizações; de outro, as pequenas comunidades familiares fechadas que realizam o ideal da autarquia. (BIGNOTTO, 2010, p. 109)

Esses dois modelos de virtude cívica e virtude moral $^{20}$ são representados respectivamente na obra de Rousseau por Genebra e Clarens, a propriedade do casal Wolmar na Nova Heloísa. Segundo Bignotto, Genebra e Clarens funcionam como ideais contrapostos da busca por um equilíbrio sempre precário e instável. Nesse sentido, as referências a uma república espartana

${ }^{19}$ Não é objeto deste artigo fazer uma reconstrução dos argumentos dos intérpretes de Rousseau que apontam para a prevalência dos aspectos republicanos em sua obra. Buscase, ao contrário, apenas exemplificar as diferentes leituras que são feitas da obra do genebrino e, a partir disso, apresentar uma proposta para acomodar a tensão entre indivíduo e comunidade. Para interpretações que consideram que a filosofia política de Rousseau acentua mais o interesse da comunidade do que aqueles do indivíduo ver, por exemplo, PINZANI, 2006, p. 250ss.; BLOON, 1997, p. 143-167; VAUGHAN, 1915, vol. 2, p. 48ss.

${ }^{20}$ Sobre essa distinção no pensamento de Rousseau ver VIROLI, 1988, p. 173ss. Sobre o conceito de virtude em Rousseau e a sua herança ver VIROLI, 1988, p. 157ss. 
ou a uma comunidade doméstica fechada funcionam apenas como ideais para realizar uma crítica do presente,${ }^{21}$ mas

não devemos toma-las isoladamente e ignorar a tensão que os habita e o fato que o pessimismo de Rousseau nunca o deixou afastar-se inteiramente das paragens do realismo político para mergulhar nas terras brumosas da pura utopia. É na tensão e no equilíbrio precário que reside o núcleo da filosofia política de Rousseau e não em seus extremos. (BIGNOTTO, 2010, p. 126s)

Nesse sentido, Rousseau em momento algum teria suprimido o indivíduo em nome da construção de um corpo político uniforme de cidadãos virtuosos. Isso por que entre o indivíduo e o Estado existe uma tensão permanente, para a qual Rousseau nunca acreditou que a vitória de um dos polos pudesse trazer felicidade (cf. BIGNOTTO, 2010, p. 142). Segundo Bignotto,

para Rousseau, a simples suposição de que uma forma de governo republicana possa estar baseada na servidão, na submissão total a uma forma política qualquer, contraria os princípios básicos da sua filosofia - em particular o lugar que ele atribui a liberdade - independentemente das dificuldades que encontramos em separar os seus diferentes significados." (BIGNOTTO, 2010, p. 145)

A República é o governo das leis, é apenas nela que é possível encontrar a liberdade e evitar a submissão a um Estado ilegítimo, que gera servidão:

Rousseau se filia a longa tradição do pensamento republicano ao fazer da liberdade e da igualdade os fundamentos da vida política e ao demonstrar que a república é essencialmente um regime das leis. Sua grande contribuição ao republicanismo moderno está em que, tendo conservado os eixos da tradição, soube pensa-los à luz de uma época que recusava a fundamentação transcendente do poder e assumia como uma de suas conquistas a ideia de indivíduo e de direitos individuais. (BIGNOTTO, 2010, p. 173)

Mas essa liberdade que surge a partir do contrato social é de uma espécie completamente distinta da liberdade natural, pois se funda na noção de bem comum que não é natural. Nesse caso, segundo Bignotto,

O grande problema da afirmação da primazia dos interesses individuais sobre os interesses coletivos não é que a proposição seja falsa, ou baseada em uma caracterização antropológica errônea, mas sim que ela supõe a continuidade entre liberdade primitiva e a liberdade política, o que para Rousseau é impossível. (BIGNOTTO, 2010, p. 143)

${ }^{21}$ Sobre a questão do ideal e sua função como elemento para a crítica política, ver SKHLAR, 1985, p. 1-32. 


\section{Isso é enfatizado no Manuscrito de Genebra:}

Esses inimigos da espécie humana terão por fim que abandonar o seu ódio, juntamente com os seus erros; que a razão que os afasta do bom caminho os trará de volta à humanidade; que aprenderão a preferir ao seu interesse aparente o interesse adequadamente bem compreendido; que se tornarão bons, virtuosos, sensíveis e, por fim, em conclusão, em vez de bandidos ferozes que pretendiam ser, que sejam o apoio mais firme de uma sociedade bem ordenada. (ROUSSEAU, 2003, p. 121)

Assim, a República não pode ser vista como o resultado natural da atuação dos interesses singulares dos indivíduos ou pela atuação do livre mercado, pois ela demanda um equilíbrio que precisa ser construído socialmente: "A ordem social é um direito sagrado que fundamenta todos os outros; no entanto, é um direito que não tem a sua fonte na natureza; baseiase assim em uma convenção". (ROUSSEAU, 2003, p. 121) Nesse sentido, Bignotto afirma que "o aspecto propriamente republicano de Rousseau é a afirmação de que, sendo a vida social um artifício, terá ela de ser criada e pensada segundo critérios morais, os quais não são dados aos homens quando ainda vivem isolados e independentes." (BIGNOTTO, 2010, p. 133) Entra em cena assim um dos elementos mais importantes do republicanismo de Rousseau, a questão da criação de uma segunda natureza para o homem:

Quem ousa empreender a instituição de um povo deve sentir-se capaz de mudar, por assim dizer, a natureza humana; de transformar cada indivíduo que, por si mesmo, é um todo perfeito e solidário em parte de um todo maior, do qual esse indivíduo recebe, de certa forma, sua vida e seu ser; de alterar a constituição do homem para fortalecê-la; de substituir por uma existência parcial e moral a existência física e independente que todos recebemos da natureza. Deve, numa palavra, arrebatar ao homem suas próprias forças para lhe dar outras que lhe sejam estranhas e das quais não possa fazer uso sem o auxílio de outrem. De sorte que, quando cada cidadão nada é e nada pode senão com todos os outros, e quando a força adquirida pelo todo é igual ou superior à soma das forças naturais de todos os indivíduos, pode-se dizer que a legislação está no mais alto grau de perfeição a que pode chegar. (ROUSSEAU, 1999, p. 50) ${ }^{22}$

As características republicanas do pensamento político de Rousseau se tornam mais evidentes quando se analisa as condições e os mecanismos utilizados para criar essa segunda natureza. Nesse sentido, pode-se indicar cinco elementos eminentemente republicanos.

\footnotetext{
${ }^{22}$ Ver ainda: "As melhores instituições sociais são aquelas que sabem desnaturar o homem, retirar-lhe sua existência absoluta para dar-lhe uma relativa, e transferir o eu para a unidade comum, de sorte que cada particular já não se julgue como tal, e sim como uma parte da unidade, e só seja perceptível no todo. (ROUSSEAU, 2014, p. 11s.)
} 
$1^{\circ}$ Aspecto: governo das leis e autogoverno. Para Rousseau o indivíduo pode viver em sociedade e ser livre somente na medida em que ele não precisa obedecer ninguém, a não ser as convenções, isto é, as leis, as quais são fruto da sua própria vontade, enquanto abarcada pela vontade geral: "Cada um de nós põe em comum sua pessoa e todo o seu poder sob a suprema direção da vontade geral; e recebemos coletivamente cada membro como parte indivisível do todos" (ROUSSEAU, 1999, p. 22). Ou ainda, "As leis não são, em verdade, senão as condições da associação civil. $O$ povo submetido às leis deve ser o autor delas; somente aos que se associam compete regulamentar as condições da sociedade." (ROUSSEAU, 1999, p. 48) Nesse caso, o poder soberano,

por mais absoluto, sagrado e inviolável que seja, não ultrapassa nem pode ultrapassar os limites das convenções gerais, e qualquer homem pode dispor plenamente do que lhe foi deixado, por essas convenções, de seus bens e de sua liberdade; de modo que o soberano nunca tem o direito de onerar mais a um súdito que a outro, porque então, tornando-se a questão particular, seu poder já não é competente. (ROUSSEAU, 1999, p. 42) ${ }^{23}$

$2{ }^{\circ}$ Aspecto: promoção de certa igualdade material como garantia da independência e da liberdade. No que diz respeito à igualdade material, Rousseau não diz expressamente que os direitos de propriedade, por exemplo, não seriam reconhecidos pelo pacto social, mas considera como conditio sine qua non para a própria liberdade dos cidadãos e para a estabilidade da comunidade política o estabelecimento de limites para a desigualdade. No Discurso sobre a Economia Política, Rousseau posiciona-se em diversas passagens sobre a relação que se estabelece entre igualdade e propriedade no Estado civil. Essa relação ocorre de forma que a propriedade é reconhecida como um fundamento do próprio contrato social, mas é também condicionada a outras finalidades da sociedade civil, tais como a redução de desigualdades extremas, o financiamento das atividades do próprio Estado e a promoção de segurança social aos cidadãos. Nesse sentido, lê-se no Tratado sobre economia política que "uma das funções mais importante do governo é impedir a extrema desigualdade de fortunas. Não retirando a riqueza dos que a possuem, mas reduzindo para todos os meios de acumulála" (ROUSSEAU, 2003, p. 22). Também no Contrato Social:

Sob os maus governos, essa igualdade é apenas aparente e ilusória: serve somente para manter o pobre em sua miséria e o rico em sua usurpação. $\mathrm{Na}$

\footnotetext{
${ }^{23}$ Ver ainda: "Há povos que, em quaisquer condições não podem ser bem governados, pois não se submetem às leis, e um governo sem leis não pode ser um bom governo" (ROUSSEAU, 2003, p. 179); "O povo da Córsega se encontra naquela condição afortunada que torna possível instituir uma boa constituição. (...) Os corsos ainda não adotaram os vícios de outras nações, mas já assumiram os seus preconceitos; são estes que precisarão ser combatidos e eliminados para que seja possível criar boas instituições." (ROUSSEAU, 2003, p. 180).
} 
realidade, as leis são sempre úteis aos que possuem e prejudiciais aos que nada têm. Donde se segue que o estado social só é vantajoso aos homens na medida em que todos eles têm alguma coisa e nenhum tem demais. (ROUSSEAU, 1999, p. 30)

(...) a respeito da igualdade, não se deve entender por essa palavra que os graus de poder e riqueza sejam absolutamente os mesmos, mas sim que, quanto ao poder, ela esteja acima de qualquer violência e nunca se exerça senão em virtude da classe e das leis, e, quanto à riqueza, que nenhum cidadão seja assaz opulento para poder comprar o outro, e nenhum assaz pobre para ser obrigado a vender-se. O que supõe, da parte dos grandes, moderação de bens e de crédito, e, da parte dos pequenos, moderação de avareza e de cobiça. (ROUSSEAU, 1999, p. 62s.).

3 o Aspecto: supremacia do interesse comum sobre os interesses particulares. A vontade geral é a expressão do interesse comum e se distingue da vontade de todos: "[v]ia de regra, há muita diferença entre a vontade de todos e a vontade geral; esta se refere somente ao interesse comum, enquanto a outra diz respeito ao interesse privado, nada mais sendo do que a soma das vontades particulares."(ROUSSEAU, 1999, p. 37) Sendo que, "o que generaliza a vontade é menos o número de votos que o interesse comum que os une (...)" (ROUSSEAU, 1999, p. 41). Assim, para Rousseau a vontade geral "tende sempre à conservação e ao bem-estar do conjunto e de todas as partes, e que é a fonte das leis, consiste na regra do que é justo e injusto, para todos os membros do Estado, com respeito a eles mesmos e ao próprio Estado." (ROUSSEAU, 2003, p. 7)

$4^{\circ}$ Aspecto: certa homogeneidade dos costumes. Segundo Rousseau, "o que torna penosa a obra da legislação não é tanto o que cumpre estabelecer como o que cumpre destruir" (ROUSSEAU, 1999, p. 62), ou seja, ao legislador cabe destruir certas características dos homens enquanto indivíduos, para que eles possam se transformar em cidadãos. Mas como fazer isso? "As opiniões de um povo nascem de sua constituição. Conquanto a lei não rege os costumes, é a legislação que os faz nascer" (ROUSSEAU, 1999, p. 153). Por isso Rousseau presta reverência a três instituições da antiguidade, criações excepcionais de três grandes legisladores: Moisés, Licurgo e Numa. Segundo ele, todos os antigos legisladores "buscaram laços que unissem os cidadãos à pátria, assim como uns aos outros, encontrando esses vínculos em determinados costumes, em cerimônias religiosas que pela sua natureza eram sempre exclusivamente nacionais." (ROUSSEAU, 2003, p. 228) Moisés criou costumes de modo a que o povo judeu não se descaracterizasse entre povos estrangeiros. Com vários ritos e cerimônias especiais "impôs a esse povo mil obrigações para tê-los sempre firme e peculiar entre os outros homens, e todos os laços de fraternidade que costurou entre os membros da sua república eram também barreiras para separá-los dos seus vizinhos" (ROUSSEAU, 2003, p. 227). Licurgo também criou uma série de normas para o povo espartano, unindo-o e assim o identificando e fez isso 
mantendo-o sempre ocupado mostrando-lhe continuamente a pátria nas suas leis, nos seus jogos, nas suas casas, nos seus amores e festivais. (...) dessa disciplina constante, enobrecida pelo seu objetivo, nasceu nele esse amor ardoroso pela pátria, que foi sempre a paixão mais forte. (ROUSSEAU, 2003, p. 227).

Numa, criou o povo romano a partir de "instituições amenas que os vinculavam entre si e à sua terra, dando assim um caráter sagrado à cidade, com rituais aparentemente frívolos e supersticiosos" (ROUSSEAU, 2003, p. 228).

Note-se que não há aqui nenhuma caracterização ou avaliação sobre o caráter moral ou justo dessas regras e costumes instituídos por esses legisladores. A nobreza da sua criação é avaliada pelos seus resultados, a saber, a partir da capacidade com que suas leis conseguiram unir os indivíduos num povo e os distinguir do resto do mundo. Rousseau reconhece isso explicitamente ao afirmar que "embora possam ser indiferentes ou mesmo maus sob certos aspectos, esses costumes terão sempre a vantagem de fazer com que os poloneses amem o seu país - desde que não haja vícios radicais - provocando-lhes uma natural repulsa a misturar-se com estrangeiros" (ROUSSEAU, 2003, p. 233). Ou ainda, "se houver a garantia de que nenhum polonês se transformará em russo, garanto que a Rússia não poderá subjugar a Polônia" (ROUSSEAU, 2003, p. 230); Portanto, a unidade dos costumes ocupa um papel central na manutenção da República:

Enquanto muitos homens reunidos se consideram como um só corpo, têm uma só vontade que se refere à conservação comum e ao bem-estar geral. Então, todos os móbeis do Estado são vigorosos e simples, suas máximas são claras e luminosas, não existem interesses confusos e contraditórios. (ROUSSEAU, 1999, 125)

$5^{\circ}$ Aspecto: educação cívica. Para Rousseau, "é certo que no longo prazo todos os povos se transformam naquilo que os governos fazem deles: guerreiros, cidadãos e homens dignos ou simplesmente populaça ou ralé, se é o que querem." (ROUSSEAU, 2003, p.14) Nesse sentido, cabe ao Estado oferecer uma educação cívica aos cidadãos e em especial às crianças, pois é somente dessa forma que as leis serão verdadeiramente respeitadas, não pelo medo de punição, mas pelo amor. Segundo Rousseau,

Não pode haver patriotismo sem liberdade, liberdade sem virtude, virtude sem cidadania. Se criarmos cidadãos, teremos tudo o que é necessário; sem eles só haverá escravos degradados, a começar pelos próprios governantes. Formar cidadãos não é trabalho de um só dia; para termos homens precisamos educá-los quando ainda são crianças. (...) Assim, por exemplo, quem for habituado desde cedo a só considerar a sua individualidade em relação com o estado; a ter consciência, por assim dizer, da sua existência só em função da existência do Estado, poderá a chegar a identificar-se em certa medida com esse todo maior, a sentir-se membro do seu país, a amá- 
lo com esse sentimento precioso que nenhuma pessoa alimenta a não ser para si mesma. (...) o governo não deveria abandonar à inteligência e aos preconceitos dos progenitores a educação dos seus filhos, já que a educação é ainda mais importante para o Estado do que para os pais; (...) As famílias se dissolvem, o Estado permanece. (ROUSSEAU, 2003, 22s)

Nas Considerações sobre o Governo da Polônia lê-se:

Cabe à educação dar aos espíritos uma formação nacional, orientando seus gostos e opiniões de modo que sejam patriotas por inclinação, por paixão e por necessidade. Ao abrir os olhos pela primeira vez a criança deve ver a pátria, e até morrer nada mais deveria ver. Todo republicano autêntico recebeu com o leite materno o amor da pátria, ou seja, o amor à lei e à liberdade. (ROUSSEAU, 2003, p. 237);

Quanto às crianças, “(...) é preciso habituá-las desde cedo às regras, à fraternidade, à competição, a viverem expostas aos seus concidadãos e a almejarem a aprovação pública." (ROUSSEAU, 2003, p. 239)

$6^{\circ}$ Aspecto: tribunal da censura e a religião civil. No último livro do Contrato Social, Rousseau defende a importância de duas instituições que devem ser responsáveis para a manutenção da República. Um deles é o tribunal da censura, pois, segundo ele,

[a]ssim como a declaração da vontade geral se faz pela lei, a declaração do julgamento público se faz pela censura. A opinião pública é a espécie de lei cujo ministro é o censor. (...) a censura pode ser útil para conservar os costumes, não, porém, para restabelecê-los. (...) A censura preserva os costumes, impedindo que as opiniões se corrompam, conservando-lhes a retidão mediante sábias aplicações (...) (ROUSSEAU, 1999, 152s.).

A outra é o estabelecimento de uma religião civil:

[h]á, pois, uma profissão de fé meramente civil, cujos artigos o soberano deve fixar, não exatamente como dogmas de religião, mas como sentimento de sociabilidade, sem os quais é impossível ser bom cidadão ou súdito fiel. Sem poder obrigar ninguém a acreditar neles, pode banir do Estado quem quer que não creia neles; pode bani-los, não como ímpios, mas como insociáveis, como incapazes de amar sinceramente as leis, a justiça, e de imolar, em caso de necessidade, sua vida ao dever. Se alguém, depois de ter reconhecido publicamente esses mesmos dogmas, se conduz como se não acreditasse neles, deve ser punido com a morte, pois cometeu o maior dos crimes: mentiu perante as leis" (ROUSSEAU, 1999, 165s)

Em suma, esses seis elementos são aspectos distintamente republicanos na filosofia política de Rousseau. 


\section{A interconexão entre os aspectos liberais e republicanos na obra de Rousseau}

Entre as diversas interpretações da obra de Rousseau não são novas as tentativas de mostrar que ela buscou estabelecer um ponto de equilíbrio entre a liberdade e a igualdade, ou ainda, como defendido por Patrick Riley, um equilíbrio entre a liberdade moderna do indivíduo, expressa no conceito de "vontade", e a igualdade inspirada na antiguidade, aspecto indicado pelo adjetivo "geral". ${ }^{24}$ Em outras palavras, a "vontade geral", conceito central do Contrato Social, é ela própria a tentativa de equilibrar dois elementos distintos, os quais, caso não estejam muito bem ajustados, tendem na maior parte das circunstâncias e situações a se excluir e até mesmo a se destruir mutuamente. ${ }^{25}$ As próprias interpretações apresentadas neste artigo (de Rawls, Cohen e Bignotto) buscam, cada uma a sua maneira, encontrar esse equilíbrio, ainda que suas leituras também estejam, às vezes, em certa tensão com algumas passagens da obra de Rousseau, as quais eles em geral atribuem ao caráter retónico e contestatório do autor.

Propor uma leitura que pretenda conciliar os aspectos à primeira vista contraditórios da obra de Rousseau é sempre, dada essa conhecida habilidade retórica e contestatória do filósofo, assumir riscos e dificilmente será possível fazer isso sem que se esbarre em dificuldades. De todo modo, levando-se em conta o que foi apresentado até aqui, propõe-se uma interpretação com os seguintes pontos: 1. o republicanismo de Rousseau segue muito de perto as teses do republicanismo inglês. 2. sua filosofia

${ }^{24}$ Cf. RILEY, 2006, p. 127ss.

25 Também Viroli (1988, p.211ss.) aponta para a difícil empreitada de Rousseau de amalgamar dois elementos de tradições políticas distintas. Por um lado a tradição de pensadores que advogam alguma forma de contrato social e, por outro, os elementos da tradição republicana clássica e moderna. O primeiro elemento se funda em uma premissa fundamentalmente individualista, o segundo faz da virtude o fundamento da ordem política. O primeiro utiliza uma forma de raciocínio normativo e abstrato, o segundo aponta para as paixões, especialmente a paixão para a liberdade e o amor a pátria. "Finalmente, e esse parece ser onde ele [Rousseau] se encontra em maior dívida, ele toma seu conceito de liberdade dos escritores republicanos. Se a tradição da teoria da lei natural the parece oferecer a melhor solução para o problema da justificação racional do governo legítimo, a tradição republicana, com a sua insistência nas virtudes cívicas e a necessidade de controle sobre as emoções, lhe fornece a maior parte das suas ideias relativas a preservação da ordem política justa." (VIROLI, 1988, p.213) Apesar dessa separação entre contexto de justificação e contexto de preservação ser útil em alguns casos, discorda-se que essa divisão esgote as razões pelas quais Rousseau combina os elementos liberais e republicanos. Além disso, discorda-se também do fato de que o seu conceito de liberdade seja eminentemente republicano e que as virtudes fundamentem a ordem política. Acredita-se que o conceito de liberdade que está na base do contrato seja fundamentalmente liberal, mas não libertário, e que as virtudes servem para garantir a liberdade por meio da implementação e preservação da igualdade, não sendo o fundamento da ordem política. Isso fica mais claro no que se segue. 
política poderia ser caracterizada como um liberalismo republicano, ${ }^{26}$ mas não um republicanismo liberal, isto é, o fundamento de sua filosofia é a noção de liberdade do indivíduo, a qual depende inexoravelmente para ser realizada do estabelecimento da igualdade formal e material entre os cidadãos, ou seja, os elementos republicanos vem para modelar e assegurar os elementos liberais.

A tese de que a liberdade do indivíduo depende da liberdade do Estado foi defendida pelos republicanos ingleses do século XVII, como por exemplo, Harrington, Milton e Sidney. ${ }^{27}$ A aproximação entre Rousseau e os teóricos republicanos ingleses tem recebido destaque em estudos recentes (cf. GIARGIA, 2008; DIJN, 2015) e as referências encontradas nos textos do genebrino, principalmente referentes à vida e à obra de Sidney, comprovam seu conhecimento e interesse pelas lições dos republicanos ingleses. ${ }^{28}$

O ponto central da tese dos republicanos ingleses é o de que os indivíduos apenas podem ser livres vivendo em Estados livres, sendo que "Estado livre" é definido como "uma comunidade na qual as ações do corpo político são determinadas pela vontade dos membros como um todo" (SKINNER, 1998, p. 55ss). Esse conceito de Estado livre possui dois elementos centrais, a saber: a) que todos, incluindo os governantes, estão submetidos ao governo das leis (aqui reside exatamente o contraste entre o Estado absolutista nos termos delineados por Hobbes, no qual o soberano não participa do pacto social e continua acima do direito, e a ideia de Estado de Direito ou do "governo da lei" defendida por republicanos como Harrington, proposta na qual todos, inclusive o governante, submetem-se ao direito); b) que a certeza de que as leis não serão arbitrárias e opressivas advém da condição de que os cidadãos devem poder participar, em igualdade de condições, de sua elaboração (aqui se destaca o ideal do autogoverno e as noções de interdependência entre liberdade negativa e positiva, isto é, a liberdade do indivíduo e a liberdade da comunidade política). Uma forte indicação de que Rousseau tinha esses dois elementos em vista ao pensar a sua filosofia política pode ser encontrada na seguinte passagem:

É inútil querer confundir a independência e a liberdade. Essas duas coisas são tão diferentes que até mesmo se excluem mutuamente. Quando cada

\footnotetext{
${ }^{26}$ Nesse sentido, segue-se aqui em linhas gerais a sugestão de Richard Dagger a respeito da possibilidade de se falar da consistência de um conceito como o de liberalismo republicano. Cf. DAGGER, 1997, p. 11ss.

${ }^{27}$ Cf. HARRINGTON, 1992; MILTON, 2008; SIDNEY, 1996.

${ }^{28}$ Nas Cartas escritas da montanha, ao discorrer sobre a queima do Contrato Social em Genebra e sobre pensadores que trataram dos fundamentos do Estado e do governo, encontra-se o seguinte excerto: "O infortunado Sidney pensava como eu, mas ele agia. Foi por sua ação e não pelo seu livro que ele teve a honra de ter seu sangue derramado." (cf. ROUSSEAU, 2006, p. 326). No Discurso sobre a origem e os fundamentos da desigualdade observa-se a seguinte referência a Sidney: "Quanto à autoridade paterna, da qual vários fizeram derivar o governo absoluto e toda a sociedade, basta observar, sem recorrer às provas contrárias de Locke e de Sidney, que nada no mundo está mais distante do espírito feroz do despotismo do que a doçura dessa autoridade que considera mais a vantagem de quem obedece do que a utilidade de quem manda." (ROUSSEAU, 2013, p. 101).
} 
um faz o que bem quer, faz-se frequentemente o que desagrada aos outros e isso não se chama um Estado livre. A liberdade consiste menos em fazer a sua vontade do que em não ser submetido à vontade de outrem; ela consiste ainda em não submeter a vontade de outro à nossa. Qualquer um que seja senhor não pode ser livre e reinar é obedecer. (...) Não conheço vontade verdadeiramente livre que não seja aquela à qual ninguém tem o direito de opor resistência; na liberdade comum, ninguém tem o direito de fazer aquilo que a liberdade de outro o proíbe de fazer, e a verdadeira liberdade nunca é destrutiva em relação a si mesma. Assim, a liberdade sem justiça é uma verdadeira contradição, pois, não importa o que se pense, tudo constrange na execução de uma vontade desordenada. Não há, pois, liberdade sem leis, nem onde alguém esteja acima das leis: pois até mesmo no estado de natureza o homem só é livre de acordo com a lei natural que comanda a todos. Um povo livre obedece, mas não serve. Tem chefes e não senhores. Obedece às leis, mas só a elas, e é pela força das leis que não obedece aos homens. Todas as barreiras que são postas nas Repúblicas e ao poder dos Magistrados são estabelecidos tão somente para garantir o recinto sagrado das leis contra seus ataques. Eles são os Ministros das leis, não seus árbitros, devem respeitá-las e não infringi-las. (ROUSSEAU, 2006, p.371s.)

O primeiro aspecto da noção de Estado livre, isto é, a preocupação de que ninguém permaneça acima do direito e da lei se constitui como o ponto de partida da argumentação de Rousseau no Contrato Social. Segundo Rousseau, no pacto social deve ocorrer a alienação total de cada associado, com todos os seus direitos, para todos e, por conseguinte, a ninguém. ${ }^{29} \mathrm{O}$ soberano é o próprio povo e, portanto, a partir do estabelecimento das leis, todos estão a ela submetidos. É exatamente com a preocupação de que ninguém permaneça acima das leis que Rousseau sustenta que as leis fundamentais que fundam a República devem ser feitas por um legislador que, após realizar seu trabalho, deve abandonar a República, pois "se aquele que manda nos homens não deve mandar nas leis, aquele que manda nas leis deve tampouco mandar nos homens" (ROUSSEAU, 1999, p. 51). O legislador deve apresentar sua proposta à assembleia e esta decide segundo a vontade geral se aceita ou não as leis que a ela estão sendo propostas. Além disso, é também nesse mesmo intuito que ele critica fortemente a ideia de

\footnotetext{
${ }^{29}$ Cf. "Bem compreendidas, essas cláusulas se reduzem todas a uma só, a saber, a alienação total de cada associado, com todos os seus direitos, a toda a comunidade. Pois, em primeiro lugar, cada qual dando-se por inteiro, a condição é igual para todos, e, sendo a condição igual para todos, ninguém tem interesse em torna-la onerosa para os demais. Além disso, como a alienação se faz sem reservas, a união é tão perfeita quanto possível, e nenhum associado tem algo a reclamar, pois, se restassem alguns direitos aos particulares, como não haveria nenhum superior comum capaz de decidir entre eles e o público, cada qual sendo em algum pondo o seu próprio juiz, logo pretenderia sê-lo em todos; o estado de natureza subsistiria e a associação se tornaria necessariamente tirânica ou vã. Enfim, cada um, dando-se a todos, não se dá a ninguém, e, como não existe um associado sobre o qual não se adquira o mesmo direito que se lhe cede sobre si mesmo, ganha-se mais força para conservar o que se tem." (ROUSSEAU, 1999, p. 21)
} 
representação. Segundo ele "numa cidade bem dirigida, todos correm às assembleias; sob um mau governo, ninguém quer dar um passo nesse sentido, porque ninguém se interessa pelo que nelas se faz, porque sabe de antemão que a vontade geral não prevalecerá e porque, enfim, os cuidados particulares tudo absorvem." (ROUSSEAU, 1999, p. 113) Ou ainda, "no momento em que o povo nomeia representantes, já não é um povo livre: deixa de ser povo." (ROUSSEAU, 1999, p.116) Outro ponto associado com a preocupação de que ninguém esteja sobre as leis é a tese da "assembleia muda", ${ }^{30}$ ou seja, a tese de que quando o legislador apresenta a lei para a aprovação do povo, não deve haver debate e discussão, pois isso poderia propiciar a criação de grupos de interesses que tivessem maior influência sobre a lei e por conseguinte, conseguissem atribuir a si próprios vantagens ou mesmo certas exceções. Enfim, todos esses aspectos, por mais problemáticos que possam ser, têm apenas uma única intenção central, a saber, evitar que alguém ou algum grupo se coloque sobre as leis.

O segundo aspecto da noção de "Estado livre", a saber, de que as leis não sejam arbitrárias e opressivas na medida em que se deve garanta as condições para a participação equitativa de todos, faz com que Rousseau procure apontar para uma série de requisitos que fomentem a "igualdade moral" entre os cidadãos, isto é, aquela igualdade que depende das convenções sociais e se distingue da igualdade natural, a qual na realidade não existe, já que ela depende dos atributos que a natureza deu a cada indivíduo. É com esse objetivo que Rousseau aponta para uma atuação positiva do Estado e do governo republicano em impedir ou dificultar a diferença de fortunas, ou seja, a promoção de uma certa igualdade material, juntamente com a preocupação com relação à virtude cívica, isto é, a importância do Estado em criar mecanismos de aproximação entre os cidadãos e a pátria, seja por meio da criação de laços afetivos entre os cidadãos, seja entre os cidadãos e as leis e os costumes da pátria. A promoção da igualdade moral tem apenas uma única intenção, evitar que se crie uma desigualdade de influência na criação das leis e na direção dos assuntos do governo, de modo que alguns indivíduos ou grupos de indivíduos se comportem como parasitas do Estado e assim, sob a aparência de seguir as leis, escravizem os demais. Nas palavras de Rousseau:

Sob os maus governos, essa qualidade [a igualdade moral] é apenas aparente e ilusória: serve somente para manter o pobre em sua miséria e o rico em sua usurpação. $\mathrm{Na}$ realidade, as leis são sempre úteis aos que possuem e prejudiciais aos que nada têm. Donde se segue que o estado social só é vantajoso aos homens na medida em que todos têm alguma coisa e nenhum tem demais. (ROUSSEAU, 1999, p. 30)

\footnotetext{
${ }^{30}$ Utiliza-se aqui a expressão de Pinzani. Cf. PINZANI, 2006, p. 226.
} 
Para sustentar o segundo elemento da interpretação aqui proposta, a saber, de que a filosofia política de Rousseau poderia ser caracterizada como um liberalismo republicano, mas não como um republicanismo liberal, isto é, de que os elementos republicanos vêm para modelar e assegurar os elementos liberais e não o inverso, pode-se partir de duas passagens do Contrato Social:

[1] Chamo, pois, República todo o Estado regido por leis, qualquer que seja a sua forma de administração, porque só então o interesse público governa e a coisa pública significa algo. [2] Todo governo legítimo é republicano (...). (ROUSSEAU, 1999, p.48)

Se indagarmos em que consiste precisamente o maior de todos os bens, que deve ser o fim de qualquer sistema de legislação, chegaremos à conclusão de que ele se reduz a estes dois objetivos principais: a liberdade e a igualdade. A liberdade, porque toda dependência particular é igualmente força tirada ao corpo do Estado; a igualdade, porque a liberdade não pode subsistir sem ela. (ROUSSEAU, 1999, p.62)

Sobre essas passagens pode-se tecer as seguintes considerações:

1. Diferença entre República e govemo republicano: como já indicado na primeira seção desse artigo, a definição de República como Estado regido por leis é um dos aspectos centrais da tradição republicana. Porém, é exatamente sobre esse tronco comum que também surge a tradição liberal. Assim que, se quisermos entender a diferença entre o liberalismo e o republicanismo, não podemos recorrer a essa característica. $\mathrm{Na}$ verdade, nesse caso, não seria equivocado considerar que essa definição de República fosse um elemento central da tradição liberal. Mas no primeiro excerto há também outro elemento relevante, a saber, a indicação de que o único governo legítimo é o governo republicano. Pode existir assim um Estado que formalmente seja uma República, mas que não possua um governo republicano. Como Rousseau indica na nota, por governo republicano "não entendo somente uma aristocracia ou uma democracia, mas de maneira geral, qualquer governo guiado pela vontade geral, que é a lei. Para ser legítimo não é necessário que o governo se confunda com o soberano, mas sim que seja o seu ministro; então, a própria monarquia é república." (ROUSSEAU, 1999, p.48n.) Em outras palavras, a noção de governo republicano está associado à vontade geral e isso pode ou não estar relacionado com as diferentes formas de governo (democracia, aristocracia e monarquia), e também pode ou não estar presente em um Estado que seja regido por leis, afinal, um governo republicano não depende apenas de que tudo esteja submetido formalmente as leis, mas de que essas leis sejam de um determinado tipo, isto é, que sejam leis que emanem da vontade geral, a qual somente pode ser alcançada se uma série de condições, e agora sim, condições republicanas estiverem presentes. 
2. Liberdade como o elemento fundamental da política: a definição de que o maior bem de qualquer sistema de legislação depende da liberdade "porque toda dependência particular é igualmente força tirada ao corpo do Estado" é tal que poderia ser encontrada em autores clássicos do liberalismo. Essa tese, por exemplo, é um dos tópicos centrais da defesa da individualidade feita por Mill em seu ensaio Sobre a liberdade, isto é, a individualidade deve ser protegida, pois da perspectiva política, é ela que garante a vitalidade do todo, de toda a sociedade e do Estado. A diferença entre Mill e Rousseau começa quando se entra na questão de como isso deve ser feito. A tese liberal de Mill é a de que o Estado deve intervir o mínimo possível e que as leis naturais do funcionamento do mercado e das opiniões funcionam como uma "mão invisível" que direciona o conjunto da sociedade para a melhor situação possível. Rousseau avaliaria a tese da mão invisível como uma proposta que não passa de uma ideologia que serve simplesmente para mascarar a servidão da vida em sociedade sob a aparência enganadora da liberdade e, nesse sentido, serviria apenas para estender guirlandas de flores sobre as correntes. Apesar de haver uma drástica divergência acerca de como a liberdade deve ser realizada, não parece haver muito conflito acerca do que é essa liberdade. Para Rousseau, assim como para a tradição liberal, liberdade é sempre a garantida da possibilidade de realização dos interesses fundamentais de cada indivíduo, de que os seus direitos individuais sejam respeitados, e de que ele jamais seja sacrificado em função do todo. Assim, de acordo com Rousseau, nenhum indivíduo pode, tal como ocorria nas repúblicas da antiguidade, sofrer ostracismo em benefício da liberdade da República.

3. Igualdade como elemento necessário para a liberdade: para Rousseau, a liberdade que surge com a fundação do Estado através do pacto social, tende rapidamente a se corroer e a morrer juntamente com o corpo político. Isso ocorre por que todas as construções humanas, não sendo naturais, mas artificiais, tendem a ser corroídas pela atuação de diferentes indivíduos e também pela modificação de certas circunstâncias sociais, históricas, político-geográficas e econômicas. Assim, a liberdade que emana imediatamente da vontade geral como um anseio íntimo dos interesses de todos os indivíduos, começa a se deteriorar assim que ela se estabelece. Para evitar que isso aconteça, é preciso "igualdade, porque a liberdade não pode subsistir sem ela". É a partir da necessidade de garantir a igualdade, ou seja, quando entra em cena a questão de como realizar e manter a liberdade, que entram em cena todos os elementos que possuem um caráter eminentemente republicano, no sentido daquilo que se entende por esse termo a partir da modernidade e em contraposição com a tradição liberal.

4. Relação de condicionalidade da igualdade para com a liberdade: ainda que isso não fique sempre tão claro na obra de Rousseau, sugere-se aqui que na sua obra se estabelece uma relação de condicionalidade entre igualdade e liberdade, em um sentido semelhante àquele que aparece, por exemplo, na hierarquia dos dois princípios da justiça como equidade sustentados por 
Rawls. Isso significa que a promoção da igualdade tem um limite e um objetivo, qual seja, sempre garantir e promover a liberdade do indivíduo. Claro que, essa liberdade que precisa ser promovida não necessariamente é aquela que o indivíduo gostaria de atribuir a si mesmo, mas somente aquela que surge e se legitima a partir da vontade geral. $O$ inverso não pode ser realizado, isto é, a liberdade não pode ser pensada como sendo condicionada pela igualdade, pois, nesse caso, sempre que a promoção e a manutenção da igualdade exigissem ou recomendassem, as liberdades e os próprios indivíduos poderiam ser sacrificados. É nesse sentido que a igualdade é condicionada pela liberdade, ou ainda, a igualdade modela a liberdade, mas sempre respeitando os limites fundamentais estabelecidos pela liberdade. A partir disso, pode-se dizer que em Rousseau, o seu republicanismo, no sentido de um governo republicano que estabelece uma série de medidas para promover a igualdade e a virtude cívica, é pensado em função de seu aspecto liberal fundamental, o qual se centra na preservação da liberdade individual. Isso não significa, contudo, que em suas propostas políticas o genebrino sempre tenha encontrado o equilíbrio em torno do qual sua própria filosofia foi estruturada. Em outras palavras, é possível encontrar passagens no Projeto de Constituição para a Córsega ou nas Considerações sobre o governo da Polônia, por exemplo, nas quais pode-se colocar fortes dúvidas sobre a manutenção dessa condicionalidade entre igualdade e liberdade, uma vez que em algumas passagens desses textos a balança pende mais para o lado da igualdade em detrimento da liberdade, comprometendo o equilíbrio.

Em suma, na filosofia política de Rousseau, os aspectos liberais e republicanos são postos em uma relação de complementaridade, mas num sentido tal que a igualdade deve ser promovida de modo que não coloque em risco a liberdade, entendida sempre como submissão de todos à lei, a qual é sempre geral e emanada da vontade geral. Por outro lado, a liberdade somente pode ser alcançada e mantida se se tomar as medidas que promovam a igualdade, que se estende para o âmbito dos costumes, da riqueza e da igualdade de consideração. Nesse sentido, com base nas definições das tradições liberal e republicana que foram oferecidas no início desse artigo pode-se dizer que a filosofia política de Rousseau busca um equilíbrio entre esses aspectos, mas um equilíbrio tal que poderia ser nomeado de liberalismo republicano, pois Rousseau percebe que a única forma de garantir uma liberdade real para os indivíduos, e não apenas uma versão ideológica de aparente liberdade, é se o Estado promover e garantir o desenvolvimento de aspectos considerados extremamente caros para a tradição republicana. Assim, para Rousseau, o republicanismo vem no sentido de modelar o liberalismo, e não o inverso. ${ }^{31}$ Essa ordem de

\footnotetext{
${ }^{31}$ Poder-se-ia criticar essa sugestão de leitura questionando-se o seguinte: que o aspecto da liberdade, atribuído aqui para tradição liberal, é a mesma que está presente na tradição republicana moderna, isto é, se o liberalismo e o republicanismo possuem um tronco comum na noção de um Estado sob o domínio das leis e se esse é o aspecto central do que
} 
complementaridade e interdependência pode ser vista, de modo geral, na própria estrutura da argumentação desenvolvida no Contrato Social, isto é, a própria obra inicia apresentando os critérios para a liberdade, em particular nos livros I e II, e mostra como isso pode ser alcançado e mantido a partir das condições da igualdade, desenvolvida de modo mais intenso nos livros III e IV.

Pode-se questionar se o ponto de equilíbrio encontrado por Rousseau para esses aspectos é de fato o melhor ou mesmo o mais adequado e eficiente. Mas apontar para a necessidade desse equilíbrio, o qual segue especificamente esta ordem, em primeiro lugar a liberdade e em segundo lugar, a igualdade, foi algo com que importantes filósofos da política concordaram e de diferentes maneiras se colocaram como seguidores de Rousseau, entre eles Kant e o próprio Rawls.

\section{Referências bibliográficas}

ALLEN, G. La volonté de tous and la volonté générale: a distinction and its significance. Ethics, v. 71, n. 4, p. 263-275, 1961.

BLOON, A. Rousseau's Critique of Liberal Constitutionalism. In: ORWIN, Clifford; TARCOV, Nathan (eds.), The Legacy of Rousseau (Chicago: University of Chicago Press, 1997).

BIGNOTTO, N. As aventuras da virtude: ideias republicanas na França do século XVIII. São Paulo: Companhia das Letras, 2010.

CASSIRER, E. A questão Jean-Jacques Rousseau. Tradução Erlon José Paschoal e Jézio Gutierre. São Paulo: UNESP, 1999.

COHEN, J. Rousseau: A Free Comunity of Equals. New York: Oxford University Press, 2010.

DAGGER, R. Civic virtues. Rights, citizenship, and republican liberalism. Oxford: Oxford University Press, 1997.

DAHL, R. A. Democracy and its critics. New Haven / London: Yale University Press, 1989.

DIJN, A. de. Rousseau and Republicanism. Disponível em: http://www.anneliendedijn.yolasite.com/resources/De\%20Dijn\%20\%20Rousseau\%20and\%20Republicanism.pdf Acesso em: 15 dez. 2015.

se chama aqui do liberalismo de Rousseau, então por que não simplesmente considerar Rousseau um republicano no sentido próprio do termo? A sugestão de se utilizar a categoria de um liberalismo republicano pode ser útil na medida em que permite apontar para a tentativa de se conciliar aspectos distintos. Além disso, parece importante apontar para o fato de que no fundamento da filosofia política de Rousseau se encontra uma preocupação e uma construção conceitual que está de acordo com a noção de liberdade que surge na modernidade, a qual é a mesma que está presente no pensamento liberal clássico, que é a da não interferência ilegítima do Estado nas questões privadas do indivíduo. Um pensamento político que fosse estritamente republicano não precisaria necessariamente se preocupar com o estabelecimento de direito individuais, por exemplo, o que, contudo, encontra-se na obra de Rousseau. 
GIARGIA, M. Disuguaglianza, ordine, virtù. Rousseau e il repubblicanesimo inglese. Milano: LED Edizioni Universitarie, 2008.

FRANKENBERG, G. Die Verfassung der Republik. Autorität und Solidarität in der Zivilgesellschaft. Frankfurt a. M.: Suhrkamp, 1997.

HARRINGTON, J.. The commonwealth of Oceana and a system of politics. Edited by J.G.A. Pocock. Cambridge: Cambridge University Press, 1992.

HOLMES, S. The anatomy of antiliberalism. Cambridge (MA) / London: Harvard University Press, 1993.

KANT, I. Sobre a expressão corrente: Isto pode ser correto na teoria, mas nada vale na prática. Trad. Artur Morão. In: A paz perpétua e outros opúsculos. Lisboa: Edições 70, 2002.

MAQUIAVEL, N. Comentários sobre a primeira década de Tito Lívio. 4. ed. Brasília: UnB, 2000.

MILTON, J. The ready and easy way to establish a free commonwealth. In: The major works. Edited with an introduction and notes by Stephen Orgel and Jonathan Goldberg. New York: Oxford University Press, 2008.

PINZANI, A. Ghirlande di Fiori e catene di ferro: istituzioni e virtù politiche in Machiavelli, Hobbes, Rousseau e Kant. Firenze: Casa Editrice Le Lettere, 2006. 2007 p. 5-14.

Republicanismo(s), Democracia, Poder. In: Veritas. Porto Alegre v. 52 n. 1 Março

RAWLS, J. O liberalismo político. 2. ed. São Paulo: Ática, 2000.

. Uma teoria da justiça. 2. ed. São Paulo: Martins Fontes, 2002.

. Lectures on the history of Political Philosophy. Ed. by Samuel Freeman. Cambridge/London: The Belknap Press of Harvard University Press, 2007.

ROUSSEAU, J.J. Cartas escritas da montanha. Tradução e notas Maria Constança Peres Pissarra et al. São Paulo: EDUC:UNESP, 2006.

. Discurso sobre a origem e os fundamentos da desigualdade entre os homens. Tradução Paulo Neves. Porto Alegre: L\&PM, 2013.

. Discurso sobre as ciências e as artes. Trad. Lourdes Santos Machado. In: JeanJacques Rousseau (Os pensadores). São Paulo: Abril Cultural, 1973b.

. Emílio, ou, Da educação. Trad. Roberto Leal Ferreira. 4.ed. São Paulo: Martins Fontes, 2014.

. O contrato social. Trad. Antonio de P. Danesi. São Paulo, Martins Fontes, 1999.

. Rousseau e as relações internacionais. Trad. Sérgio Bath. São Paulo: Imprensa oficial do Estado, 2003.

RILEY, P. Rousseau's general will. In: RILEY, Patrick (Ed.). The Cambridge Companion to Rousseau. Cambridge: Cambridge University Press, 2006.

SHKLAR, J. Men and citizens. a study of Rousseau's social theory. Cambridge: Universtity Press, 1985. 
SIDNEY, A. Discourses concerning government. Edited by Thomas G. West. Indianapolis: Liberty Fund, 1996.

SKINNER, Q. Liberdade antes do Liberalismo. Tradução Raul Fiker. São Paulo: UNESP, 1998.

TOCQUEVILle, A. A Democracia na América. São Paulo: Martins Fontes, 2000.

VAUGHAN, C. E. Introduction. In: The political writings of Jean-Jacques Rousseau. Edited from the original manuscripts and authentic editions. Cambridge: Cambridge University Press, 1915.

VIROLI, M. Jean-Jacques Rousseau and the 'Well-Ordered Society'. Cambridge: University Press, 1988.

WALDRON, J. Liberal Rights: collected papers 1981-1991. New York: Cambridge University Press, 1993.

\section{Endereço Postal:}

Departamento de Filosofia Centro de Ciências Humanas, Letras e Artes Av. Senador Salgado Filho, s/n - sala 703- Campus Universitário Lagoa Nova - Natal - RN - Brasil Data de recebimento: 31-01-2016

Data de aceite: $22-12-2016$ 